\title{
Asian Soybean Rust Resistance: An Overview
}

\author{
Carlos Renato Echeveste da Rosa1*, Carlos Roberto Spehar2 and Jean Q. Liu3 \\ ${ }^{1}$ Du Pont Pioneer - Soybean Plant Pathology, 73310-970, Planaltina, DF, Brazil \\ ${ }^{2}$ Universidade de Brasilia - Faculdade de Agronomia e Medicina Veterinária, 70910-970, Brasilia, DF, Brazil \\ ${ }^{3} A R Q$ Solutions, Chicago, IL, 60613, USA
}

\begin{abstract}
Asian soybean rust caused by Phakopsora pachyrhizi, occurs in all soybean production regions of the world. Rust is the most destructive foliar disease of soybean and can cause yield losses of over $80 \%$. To date, six race-specific resistance genes have been identified in plant introductions. However, races of $P$. pachyrhizi able to overcome the resistance conferred by these genes have evolved. Due to the limited availability of resistant varieties, fungicide application is the only management tool available for farmers, which significantly raises the production cost and the risk of environmental and human contamination. Thus, the transfer of resistance genes through classical breeding followed by marker-assisted selection allows the development of resistant varieties and their use as an efficient and cost-effective method for controlling soybean rust. The objective of this review is to provide a broad overview of the Asian soybean rust resistance, and a useful tool to guide future researches as well.
\end{abstract}

Keywords: Asian soybean rust; Phakopsora pachyrhizi; Soybean; Glycine max; Genetic resistance; Rpp gene.

\section{Introduction}

Soybean is one of the most important economic crops as a source of protein and oil. Biotic stresses such as pathogens, insects and weeds can cause negative impacts on its production. Among the diseases, Asian soybean rust caused by Phakopsora pachyrhizi (Sydow. \& Sydow.)is the most destructive, and over $80 \%$ losses are common when environmental conditions are conducive to disease development (Figure 1). The infected plants undergo defoliation and early maturation in relation to non-infected plants, which causes reduction in weight and quality of the grains. Due to the limited availability of resistant varieties, the fungicide application is the only management tool available for farmers, which significantly raises the production cost and the risk of environmental and human contamination (Figure 2). In addition, some pathogen populations have shown increased tolerance to certain fungicides [1]. Thus, the search for resistant varieties is a critical strategy for economically and environmentally sustainable control.

Asian soybean rust is present in the most countries growing soybeans. The first report of rust epidemic was around 1914 in Southeast Asian countries. However, until the middle of last century the rust fungus reports occur only in East Asia and Australia. In 1970 it was reported in India [2], in 1976 in Puerto Rico [3] and in 1994 in Hawaii [4]. Probably the introduction of soybean rust in Africa in 1975 took place from urediniospores transported by air currents from west of India [5]. In 2001, the fungus was first detected in Brazil and Paraguay [6-9] and in 2003 in Argentina [7-10]. In the continental US, the pathogen was first reported in 2004 [11], and the rust epidemics have been limited to the southern states, with reduced movement toward producing regions of the North [12]. There are no reports of negative economic effects due to soybean rust in the United States, although there are up to $33 \%$ yield losses documented in experiments with no fungicide application [13]. In Argentina, soybean rust epidemics occur every year, usually late in the growing season and significant losses are limited to a few north locations of the country [10].

The main difference in the effect of the rust between Argentina, Brazil and the US is due to the unique environmental characteristics of Brazil that increase the rust risk. The environmental condition in Brazil is much more conducive to rust development than that in the
US and Argentina. Uredinia survive only in areas of southern US and northern Argentina due to low temperatures during the winter at high latitudes [14]. The high rainfall regime in the summer in Brazil increases substantially the risk of losses caused by Asian soybean rust when compared with Argentina and the US. In Brazil, the main factors for rust epidemics are a great soybean field extension and the continued monoculture, which favors urediniospores production and dissemination, and accelerates race shifts. The favorable climate, fungicide ineffectiveness, high plant density, sowing period from September to January, pathogen survival in volunteer plants of soybean and secondary hosts, are additional factors that decrease efficiency of control measures of the disease [15].

Sources of resistance have been reported and to date six dominant genes have been identified: Rpp1 [16], Rpp2 [17], Rpp3 [18], Rpp4 [19], Rpp5 [20] and Rpp6 [21]. These genes are not effective against all populations of $P$. pachyrhizi [22]. The transfer of resistance genes through classical breeding or through marker-assisted selection allow to develop resistant varieties and their use as an efficient and costeffective method for soybean rust control. Therefore, studies on the inheritance of resistance in soybean to $P$. pachyrhizi are very important for varieties development. Many breeding programs have used some identified resistance genes with success, although the diversity of rust isolates present in the nature is a continuous challenge. The objective of this review is to provide a broad overview of the soybean rust resistance, and a useful tool to guide future researches as well.

\section{The Host}

Glycine $\max ($ L.) Merr, originally from northeastern China, has

*Corresponding author: Carlos Renato Echeveste da Rosa, Du Pont Pioneer Soybean Plant Pathology, 73310-970, Planaltina, DF, Brazil, Tel: +556184054119; E-mail: carlos.echeveste@hotmail.com

Received September 20, 2015; Accepted October 05, 2015; Published October 10, 2015

Citation: Rosa CRE, Spehar CR, Liu JQ (2015) Asian Soybean Rust Resistance: An Overview. J Plant Pathol Microb 6: 307. doi:10.4172/2157-7471.1000307

Copyright: @ 2015 Rosa CRE, et al. This is an open-access article distributed under the terms of the Creative Commons Attribution License, which permits unrestricted use, distribution, and reproduction in any medium, provided the original author and source are credited. 


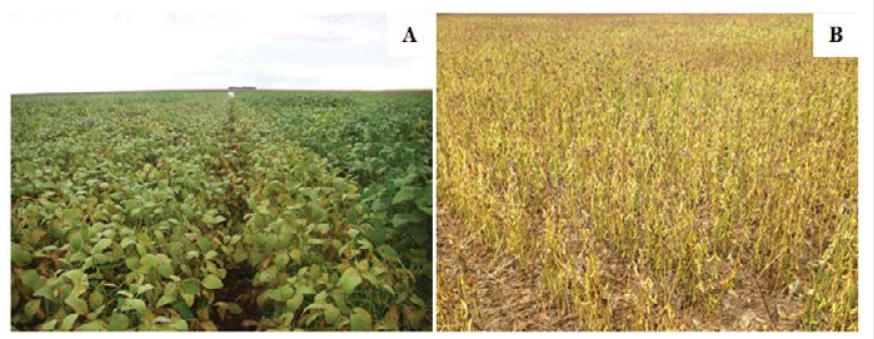

Figure 1: Soybean crop during the pod fill stage severely infected by Phakopsora pachyrhizi $(\mathrm{A})$, and the same crop field a week later, presenting intense defoliation (B). Location of pictures: Campo Verde city, Mato Grosso

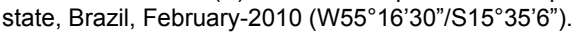
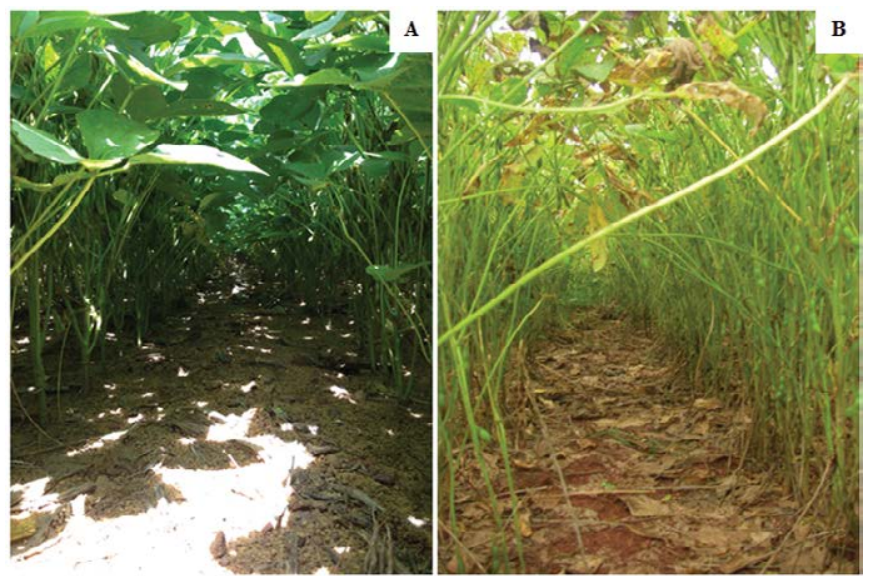

Figure 2: Aspect of soybean canopy with (A) and without (B) fungicide application to control Phakopsora pachyrhizi. It is noticeable the high amount of leaves above ground where the fungicide was not applied. Location of pictures: Campo Verde city, Mato Grosso state, Brazil, February-2010 (W55¹6'30"/S15³5'6”).

emerged as a domesticated specie by the eleventh century BC. Soybean belongs to the Magnoliophyta Division, Magnoliopsida Class, Fabales Order, Fabaceae Family, Faboideae Subfamily, Glycine gender [23]. Glycine max is a domesticated specie over the 18 known species of the genus Glycine, and its diploid number of chromosomes is forty. Soybean is cultivated in temperate and subtropical regions as oil and protein source.

Soybean is a legume species that has a great adaptability to different latitudes, climate and soil conditions. Their grains are important source of protein and vegetable oil for human and animal diet. Soybeans contain about $20 \%$ oil and $40 \%$ protein in the form of essential amino acids. The oil is used mainly for human consumption and as an industrial raw material, and the beans after oil extraction are used for animal feed [24].

In Brazil, the introduction of soybeans in a commercial scale occurred in the 1930's, using American varieties originally adapted to cultivation in the southern US. However, the large increase in area and production of soybeans took place in the 80 's, when the success in breeding allowed the expansion of culture to the Cerrado areas [25]. From an area equal to 1.29 million hectares and a production of 2.2 million tons in 1980, the region began to grow to 5.08 million hectares, with a production of 10.3 million tons in 1989. Currently soybean is one of the most important crops produced in Brazil and accounts for about $46 \%$ of the grain produced in the country. In the 2014-2015 season, the Brazilian soybean production reached 96 million tons, an increase of
$11.5 \%$ over the previous season [26]. Exports by the production chain of the oilseed reached nearly US $\$ 31$ billion and represented $31 \%$ of total exports from Brazil agribusiness [27]. Worldwide soy is cultivated in about 118 million hectares, with production estimated at 315 million tons [28]. Brazil is the second largest producer and accounts for about $30 \%$ of world production of oilseeds. The US is the first producer, with an output of 108 million tons in an area of 33.6 million hectares, representing $34 \%$ of total world production.

\section{The Pathogen}

The fungus that causes Asian soybean rust belongs to the Fungi Kingdom, Basidiomycetes Class, Uredinales Order, Phakopsoraceae Family, Phakopsora pachyrhizi specie. To date, the described fungus stages were uredinial, teleomorphic and basidial. The aecial stages have not been reported yet [29]. Like all fungi of the group, $P$. pachyrhizi is a biotrophic pathogen that requires a living host to grow and survive.

Naturally, $P$. pachyrhizi infects 31 species in 17 genera of legumes [30]. The main hosts are Glycine max, G. soja, Pachyrhizus erosus, Pueraria lobata and Vigna unguiculata. According to Yeh et al. [31] and Bromfield [2] the fungus could attack up to 87 and 95 hosts, respectively.

Symptoms caused by soybean rust are different from those caused by other types of rusts. The uredinia are the fruiting bodies, which produce the urediniospores released through an ostiole. The symptoms of soybean rust are characterized by small brownish to dark brown lesions, with one or more uredinia mainly on the bottom side of the plant leaflets. The lesions tend to be angular with 2 to $5 \mathrm{~mm}$ in diameter. May also occur on petioles, pods and stems. The color of the lesions varies with age and with the interaction between the host genotype and the pathogen isolate. The new lesions are initially light brown, becoming darker with the age [32].

The urediniospores are the primary inoculum of soybean rust. These are asexual, small, lightweight spores, which are removed from uredinia when the infected leaf surface is dry. After removal, the air currents can transport the spores over long distances, which explain its spread from one field to another. In the presence of water and temperature between 21 and $25^{\circ} \mathrm{C}$, the urediniospores deposited on the host leaf surface begins the germination process and infection [32]. The penetration of the parasite occurs directly through the cuticle and epidermal cell wall of the host. The direct penetration rather than through the stomata, is a characteristic that differentiates $P$. pachyrhizi from other rusts fungi. The colonization begins shortly after penetration, the primary branching hyphae gives rise to formation of a dense mycelium filling the intercellular spaces and inserting haustoria in the mesophyll and epidermal cells. The fungus reproduction begins approximately at eight days after infection, and its first evidence is the hyphae aggregation forming the uredinia primordium. Uredinia haves light brown to red brown appearance. In about 3 to 4 days, it starts the production of urediniospores. According Alves et al. [33], the latency period length varies with the temperature, being shorter for temperatures around $23^{\circ} \mathrm{C}$, in agreement with previous studies of Melching et al. [34].

\section{Pathogen Variability}

Regarding the variability of the pathogen, the asexual production of urediniospores suggests a low genetic diversity, with a small number of clonal lineages and recurrent events [35]. In general, data from different molecular markers shows that the genetic diversity in $P$. pachryrhizi is low between large geographic areas and high when considering the variation within local populations. The high capacity of dispersion over long distances enables virulent genotypes of $P$. pachyrhizi move 
quickly between different populations [36]. In Nigeria, $P$. pachyrhizi has approximately $90 \%$ of their genetic diversity within the soybean fields, with little diversity distributed among the fields [35,37-39].

On the other hand, the presence of resistance genes in the host did not lead to reduction of frequency of virulence genes in pathogen populations. The probable explanation for this is that asexual way is not the unique reproduction mechanism of $P$. pachyrhizi. The anastomosis of the germ tube and hyphae, and the possibility of parasexual cycle $[40,41]$, contribute to increase the genetic diversity of the pathogen. Thus, breeding for soybean rust resistance, should consider the likelihood of conversion of avirulent to virulent isolates. In addition, the local development of varieties containing only one resistance gene exposes it to these pathogen populations containing the full range of genetic variation present at regional level.

The size of the genome of $P$. pachyrhizi was estimated between 300 and $950 \mathrm{Mb}$ depending on the analysis method used [42]. Igor Grigoriev provided similar information, suggesting a genome greater than $850 \mathrm{Mb}$ [43]. However, due to ignorance about the degree of heterozygosity between or within the dikaryotic fungus genome, this size can be overrated. It is possible that the genome of $P$. pachyrhizi has sustained a high level of gene duplication during evolution with an important activity of transposable elements, which can explain the enormous size of the estimated genome for that species.

\section{Resistance}

The plants generally have two main defense mechanisms against pathogens, race-specific and race-nonspecific resistance. Race-specific resistance is controlled by single $\mathrm{R}$ genes and generally less durable. In contrast, race-nonspecific resistance is a polygenic trait and more durable [44].

During the early phases of infection, all pathogen classes deliver effector molecules into the plant cell to enhance microbial fitness. In response, plants have evolved a dynamic immune system to defend themselves against plant pathogens. The perception of pathogen associated molecular patterns (PAMPs) by plant extracellular pathogen recognition receptors (PRRs) is the first stage of plant basal defenses. The PAMPs are essential structures or components that are conserved throughout the whole classes of pathogens, including oligogalacturonides, ergosterol, bacterial flagelin, xylanases, cold-shock protein and lipopolysaccharides. Such response is referred to as PAMPtriggered immunity (PTI) and activates a myriad of process, including mitogen-activated protein kinase (MAPK) cascades, production of reactive oxygen species (ROS). According to the zig-zag model, proposed by Jones \& Dangl [45], there are numerous PRRs in plants to recognize PAMPs and to initiate basal defense responses. However, some pathogens can secrete effectors to evade recognition by plant PRRs and to promote pathogen growth and virulence, called effectortriggered susceptibility (ETS). In response to ETS, host plants trigger $\mathrm{R}$ proteins to interact directly or indirectly with pathogen effectors or avirulence (Avr) proteins, and induce a stronger defense response, referred to as effector-triggered immunity (ETI) [44]. ETI triggers salicylic acid (SA) biosynthesis and signaling, leading to local and systemic acquired resistance (SAR) against biotrophic pathogens.

According to Van de Mortel [46], a biphasic gene response to $P$. pachyrhizi infection was seen in resistant and susceptible genotypes. The early transcriptional response observed in susceptible and resistant plants might represent a general response of soybean to the non-specific recognition of any pathogen, presumably by interaction with PAMPs. By contrast, the second likely response relates to $\mathrm{R}$ gene detection of $P$. pachyrhizi, typically mediated by ETI pathway. Typically ETI culminates in hypersensitive cell death (HR) that retard pathogen growth, particularly in interactions involving haustorial parasites.

There are three types of soybean reaction to infection by $P$. pachyrhizi, which are associated with qualitative resistance genes (Figure 3). The first type is the immunity (IM) or complete resistance, without the presence of reproductive structures, such as uredinia or urediniospores. The second type is incomplete (or partial) resistance, which leads to the development of red brown (RB) lesions. According Parlevliet [47] and Ribeiro Do Vale [48], incomplete resistance allows some growth or reproduction of the pathogen in the host tissues. Finally, the tan colored lesions (TAN), indicative of susceptibility [49]. Either IM or RB reaction are initiated with the early perception of the pathogen avirulence proteins by plant $\mathrm{R}$ proteins, according the classical gene-for-gene resistance theory [50]. This incompatible interaction is followed by a localized programmed cell death, called hypersensitive response (HR), to limit the pathogen growth. On the other hand, TAN reaction means a compatible interaction, without the perception of the pathogen by the plant. Studies of host-pathogen interaction show that RB lesions tend to have longer latency period, smaller and fewer uredinia than the TAN lesions. Although RB type injury can also vary in color from light red to dark red, and sometimes have larger lesions than the TAN type. These observations suggest that the color of the lesions may not be a reliable indicator of susceptibility or resistance $[2,51,52]$.

The wide variation in the type of reaction, color and intensity of sporulation observed in the field can be a difficulty factor in genotype characterization studies [53]. Although the type of lesions are widely used in detached leaves and seedlings inoculations studies, the appearance of rust lesions in adult plants is often different from that originally reported by Bromfield \& Hartwig [17]. Besides the influence of the host genotype and levels of pathogen sporulation, the color of the lesions varies with their age, especially in the field where the infection events are continuous. In the work of Miles et al. [49], the IM and RB reactions were considered the unique forms of resistance expression. However, partial resistance also occurred in the interaction between $P$. pachyrhizi and soybeans, since differences were observed between the lines with TAN lesions. The variation in the number of uredinia is one of the parameters to be considered in the differentiation of genotypes with partial resistance and is inversely correlated with yield $[2,51,54,55]$.

The incompatible interaction expressed as IM phenotype is mediated by Rpp1 gene [56], while the resistance conferred by the other genes is characterized by the formation of RB lesions, and limited

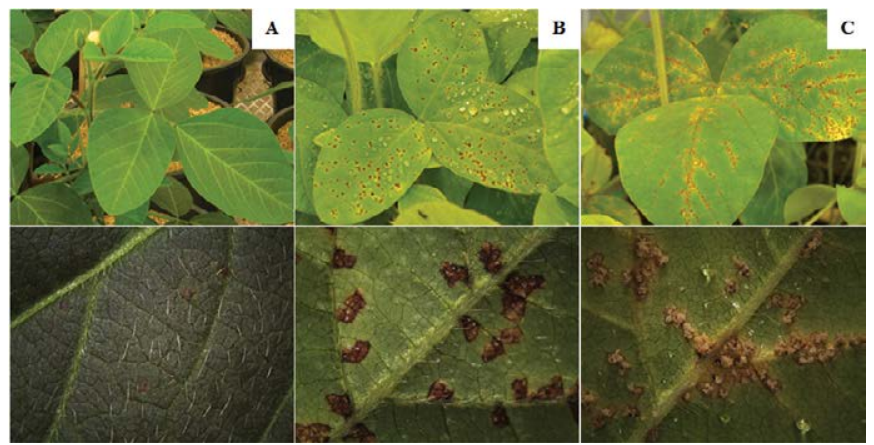

Figure 3: The three types of soybean responses to infection by Phakopsora pachyrhizi: Immunity or complete resistance (A), RB type lesions or incomplete resistance $(B)$ and TAN type lesions indicative of susceptibility $(C)$. 
growth and sporulation [51]. Soybean varieties with partial resistance allow the development of a few lesions and limited sporulation during the growing season [55]. Race-nonspecific resistance has also been observed. It acts by reducing the amount and rate of rust development, even if the type of infection is similar to that produced in highly susceptible varieties [2]. This type of resistance can be effective against most of the pathogen population, being more useful than the racespecific resistance. The difficulties associated with race-specific and race-nonspecific resistance have led to the search for new types of resistance such as tolerance [57]. Tolerance is the relative ability of soybeans to produce under the stress caused by rust. This type has been used to minimize yield losses associated with soybean rust [58,59].

The first report of race-specific resistance in soybean to $P$. pachyrhizi occurred in the 70's [60]. In 1975, the US Department of Agriculture (USDA), in cooperation with the Asian Vegetable Research and Development Center (AVRDC), tested approximately 16,000 genotypes against a mixture of five isolates. They found 805 accessions with low severity or RB lesions, which were considered as a potential resistance sources. However, it was not possible to determine whether these resistant genotypes represented new sources of resistance genes or just alternative sources for the same four genes already known at that time. This is still an important question to be answered about the new resistance sources identified in recent studies. Studies conducted in Australia by McLean [61] and McLean \& Byth [16] found that a single dominant gene controls resistance of PI 200492 to certain races of $P$. pachyrhizi. At the same time, Singh \& Thapliyal [62] reported that PI 462312 also carries a single dominant gene.

The first report indicating the occurrence of variability in the pathogen population was in 1980. In tests carried out by Bromfield \& Hartwig [17], the PI 200492 and PI 462312 showed susceptibility to an isolate from Taiwan and resistance to an isolate from India. On the other hand, PI 230970 and PI 230971 had just RB lesions when inoculated with isolates from Australia, India, Taiwan and Philippines. With the same set of varieties, Hartwig \& Bromfield [18] indicated that $R p p 1, R p p 2$ and $R p p 3$ genes not had the same spectrum of reaction against different rust isolates. While $R p p 1$ and $R p p 3$ genes conferred resistance only to an isolate from India, the $R p p 2$ gene conferred resistance to isolates from India and Taiwan. When combined, the Rpp1 and $R p p 3$ genes conferred intermediate reaction between immunity and incomplete resistance. With these results, they concluded that PI 200492, PI 230970 and PI 462312 carry different dominant resistance genes located on different locus. According to the authors', the isolates able to attack the PI 200492 have become prevalent in the fungal population in Taiwan. Since PI 230971 and PI 230971 were resistant to four isolates, these varieties become fundamentally importance for the breeding programs at that time. During this period, the Asian Vegetable Research and Development Center (AVRDC) recommended the varieties PI 200492, PI 462312, PI 230970, PI 230971, PI 293871A, PI 239871B, PI 459024, PI 459025, Tainung 4, Taita Kaohsiung No.5 and Wayne, as a set for rust isolates differentiation [63].

Between 2000 and 2010, with the incorporation of Rpp1 and Rpp2 genes in the Asian breeding programs, the resistance conferred by these genes was quickly defeated [64]. Similarly, the effectiveness of these genes was lost only two years after soybean rust had been reported in Brazil [7].

According to studies from Miles et al. [49], the rust severity was not related to the type of lesions. Among the varieties with RB lesions, PI 561356 and PI 594538A showed lower levels of severity than PI 230970, PI 423972 and PI 459025B, who were the varieties with higher rates of severity. On the other hand, among the varieties with TAN lesions and low levels of severity, PI 548463, PI 548484 and PI 549017 produced similar numbers and sizes of uredinia as from the susceptible variety Williams, indicating no relationship between the severity of the disease and the reproduction of the fungus.

Walker et al. [53], studying the field reaction of reported resistance genes in the southern United States, noted that Rpp1 gene, present in PI 200492, and Rpp6 gene, in PI 567102B, still conferred high levels of resistance. The varieties carrying $R p p 2, R p p 3, R p p 4$ or $R p p 5$ showed incomplete resistance and moderate levels of rust development when compared to susceptible controls. Although Rpp2, Rpp3 and Rpp4 genes have conditioned lower levels of resistance, this moderate resistance was stable at the different sites. Regarding the resistant varieties reported in the literature, but whose genes have not been mapped yet, the resistance in PI 567104B was similar of PI 567102B (Rpp6). Coincidentally both these varieties came from the same research center in Indonesia, yet the relationship between them is unknown. PI 416826A, PI 417125 , PI 567024, PI 567025A, PI 567034 and PI 605823 also showed good resistance to most field isolates of $P$. pachyrhizi. The authors reported no immunity among the varieties tested and a low frequency of sporulating uredinia, even in highly resistant accessions, such as PI 200492 and PI $567102 \mathrm{~B}$. This indicates that in some regions, the fungal population is heterogeneous and contains one or more isolates able to overcome the resistance conferred by Rpp1 and Rpp6 genes. They also observed that moderate resistance conditioned by certain genes make it difficult to distinguish between race-specific and race-nonspecific resistance. An example is the case of PI 506764 (Hyuuga), carrying resistance genes $R p p 3$ and $R p p 5$ [65], but whose classification field was the same of PI 200492 (Rpp1) and PI 462312 [Rpp3].

Recently, Chen et al. [66] identified a new resistance allele on chromosome 18, where several alleles of Rpp1 family have been identified. According to the authors, the identified locus differs from those previously identified in PI 200492 [67], PI 587886 and PI 587880A [68], PI 561356 [69] and PI 594538A [70]. According to Ray et al. [68], the resistance observed in PI 587880A and PI 587886 is controlled by an $R p p 1$ allele with incomplete dominance. The presence of RB lesions in heterozygous individuals (Rpp1/rpp1), and IM or TAN lesions in homozygous (Rpp1/Rpp1 or $r p p 1 / r p p 1)$ individuals are indicative of incomplete resistance conferred by $R p p 1$. Furthermore, the presence of three classes of lesions (IM, RB and TAN) in mapping populations is also an indicative of incomplete dominance. In this sense, Smith et al. [71] also conclude that the gene action of an Rpp1 allele mapped in PI 587905 can be dominant or incompletely dominant, depending on the age or development stage of plants. So far, resistance alleles to soybean rust were identified and mapped in different loci of chromosomes 3, 6, 16 and 18 (Table 1).

Resistant varieties are useful tools to reduce the economic losses caused by Asian soybean rust. However, varieties with a single resistance gene tend to be readily broken $[2,64,72]$. The effectiveness of the racespecific resistance is often of short duration, especially in biotrophic pathogens like $P$. pachyrhizi, with high virulence variability. Varieties with two pyramided resistance genes tend to express greater durability of resistance than varieties with a single gene $[73,74]$. Lemos et al. [75] and Yamanaka et al. [76] reported that a variety with three resistance genes ( $R p p 2, R p p 4$ and $R p p 5$ ) showed significantly higher resistance than its ancestor, showing that pyramiding strategy is effective to increase the rust resistance.

The main factors that determine which strategies and methods should be employed in rust resistance breeding programs include 


\begin{tabular}{|c|c|c|c|c|}
\hline VARIETY & GENE & CHROMOSOME (LINKAGE GROUP) & MOLECULAR MARKER & REFERENCE \\
\hline PI 200492 & Rpp1 & $18(\mathrm{G})$ & Satt191 - Sat064 & McLean \& Byth, 1980; Hyten et al., 2007. \\
\hline PI587866 & Rpp1 & $18(\mathrm{G})$ & Satt191 - Sat064 & Ray et al., 2009. \\
\hline PI 587880A & Rpp1 & $18(G)$ & Satt191 - Sat372 & Ray et al., 2009. \\
\hline PI 561356 & Rpp1 & $18(G)$ & SSSR50 - SSSR1859 & Kim et al., 2012. \\
\hline PI 587905 & Rpp1 & $18(G)$ & Sat064 - SSR66/Satt191 - Sat_372 & Hossain et al., 2014; Smith et al., 2015. \\
\hline PI 594760B & Rpp1 & $18(G)$ & Sat117 - Sct187 & Garcia et al., 2011. \\
\hline PI 594767A & Rpp1 & $18(G)$ & Sat064 - Satt191 & Hossain et al., 2014. \\
\hline PI 594538A & $R p p 1-b$ & $18(G)$ & Sat064 - Sat372 & Chakraborty et al., 2009. \\
\hline PI 230970 & Rpp2 & $16(\mathrm{~J})$ & Sat255 - Satt620 & Hartwig \& Bromfield, 1980; Silva et al., 2008. \\
\hline PI 224270 & rpp2 & $16(\mathrm{~J})$ & Satt215 - Sat361 & Garcia et al., 2008. \\
\hline PI 462312 & Rpp3 & $6(\mathrm{C} 2)$ & Satt460 - Sat263 & Hartwig \& Bromfield, 1983; Hyten et al., 2009. \\
\hline PI 416764 & Rpp3 & $6(\mathrm{C} 2)$ & Sat263 - Satt307 & Hossain et al., 2014. \\
\hline PI 567099 & rpp3 & $6(\mathrm{C} 2)$ & Satt460 - Staga001 & Ray et al., 2011. \\
\hline PI 506764 & Rpp3/Rpp5 & $6 / 3(\mathrm{C} 2 / \mathrm{N})$ & Satt460 - Sat263/Sat275 - Sat280 & Monteros et al., 2007; Kendrick et al., 2011. \\
\hline PI 200487 & Rpp3/Rpp5 & $6 / 3(\mathrm{C} 2 / \mathrm{N})$ & Satt460 - Sat263/Sat275 - Sat280 & Garcia et al., 2008; Kendrick et al., 2011. \\
\hline PI 471904 & Rpp3/Rpp5 & $6 / 3(\mathrm{C} 2 / \mathrm{N})$ & Satt460 - Sat263/Sat275 - Sat280 & Kendrick et al., 2011. \\
\hline PI 459025 & Rpp4 & $18(\mathrm{G})$ & Satt288 - AF162283 & Hartwig, 1986; Silva et al., 2008. \\
\hline PI 459025B & Rpp4 & $18(G)$ & Satt288 - AF162283 & Silva et al., 2008. \\
\hline PI 200456 & rpp5 & $3(N)$ & Sat275 - Sat280 & Garcia et al., 2008. \\
\hline PI 200526 & Rpp5 & $3(N)$ & Sat275 - Sat280 & Garcia et al., 2008. \\
\hline PI 567102B & Rpp6 & $18(G)$ & Satt324 - Satt394 & Li et al., 2012. \\
\hline
\end{tabular}

Table 1: Soybean varieties used as a source of resistance to Phakopsora pachyrhizi and the molecular information of the mapped genes in soybean genome.

the genetic distance between the varieties to be improved and the resistance donor, the screening methods, the genetics of resistance and the number of characteristics to be improved [77]. The soybean breeding for rust resistance has focused on qualitative genes, which have stability limitations in the control of diseases. Furthermore, the presence of multiple virulence genes in the pathogen population, and the lack of multiple resistance genes in the host gives a competitive advantage to rust, and makes the race-specific resistance less effective and short as compared to race-nonspecific resistance [78]. Ribeiro et al. [79] suggest that breeding for race-nonspecific resistance is more effective to achieve durable resistance. Currently, with the launch of new resistant varieties, it is expected the appearance of new rust races. Therefore, it is crucial to make continued efforts on identifying newer genes for resistance, developing and refining molecular markers for use in breeding programs for Asian soybean resistance.

\section{References}

1. Godoy CV, Silva LHCP, Utiamada CM, Siqueri FV, Lopes ION, et al. (2009) Eficiência de fungicidas para o controle da ferrugem aisática da soja, Phakopsora pachyrhizi, na safra 2009/10: resultados sumarizados dos ensaios cooperativos. Londrina, Brasil: Embrapa Soja publication n. 69.

2. Bromfield KR (1984) Soybean Rust. Monograph no.11. St. Paul, USA: American Phytopathological Society, Dissertation.

3. Vakili NG, Bromfield KR (1976) Phakopsora rust on soybeans and other legumes in Puerto Rico. Plant Disease Report 60: 995-999.

4. Killgore E, Heu R, Gardner DE (1994) First report of soybean rust in Hawaii. Plant Disease 78: 1216.

5. Caldwell P, Laing M (2002) Soybean rust - A new disease on the move. Characterization of Phakopsora pachyrhizi (Uredinia and telia) in Argentina. Plant Disease 89: 109.

6. Yorinori JT, Paiva WM, Frederick RD, Costamilan LM, Bertagnolli PF, et al. (2002) Epidemias de ferrugem da soja (Phakopsora pachyrhizi) no Brasil e no Paraguai, nas safras 200/01 e 2001/02. In: Congresso Brasileiro de Soja. Foz do Iguaçu, Brazil: 94

7. Yorinori JT, Paiva WM, Frederick RD, Costamilan LM, Bertagnolli PF, et al. (2005) Epidemics of soybean rust (Phakopsora pachyrhizi) in Brazil and Paraguay from 2001-2003. Plant Disease 89: 675-677.

8. Costamilan LM, Bertagnolli PF, Yorinori JT (2002) Perda de rendimento de grãos de soja causada pela ferrugem asiática (Phakopsora pachyrhizi). Fitopatologia Brasileira 27: 100

9. Reis EM, Casa RT, Michel C (2002) Ocorrência de epidemia da ferrugem da soja no Rio Grande do Sul na safra 2001/2002. Fitopatologia Brasileira 27 : 198-199.

10. Ivancovich A (2005) Soybean rust in Argentina. Plant Disease 89: 667-668.

11. Schneider RW, Hollier CA, Whitam HK, Palm ME, McKemy JM, et al. (2005) First report of soybean rust caused by Phakopsora pachyrhizi in the continental United States. Plant Disease 89: 774.

12. Christiano RS, Scherm H (2007) Quantitative aspects of the spread of asian soybean rust in the southeastern United States, 2005 to 2006. Phytopathology 97: 1428-1433.

13. Mueller JD, Koenning SR, Kemerait RC, Phipps PM (2008) Soybean Rust Management in the Mid-Atlantic Region. Clemson, USA: Clemson University Extension Service publication.

14. Pivonia S, Yang XB (2004) Assessment of potential year round establishment of soybean rust throughout the world. Plant Disease 88: 523-529.

15. Yorinori JT, Nunes Junior J (2006) Soybean germplasm with resistance and tolerance to "Asian" rust and screening methods. In: South American Workshop On Soybean Rust. Londrina, Brasil: Embrapa Soybean, p: 13.

16. McLean RJ, Byth DE (1980) Inheritance of resistance to rust (Phakopsora pachyrhizi) in soybeans. Australian Journal Agriculture Research 31: 951-956.

17. Bromfield KR, Hartwig EE (1980) Resistance to soybean rust and mode of inheritance. Crop Science 20: 254-255.

18. Hartwig EE, Bromfield KR (1983) Relationships among three genes conferring specific resistance to rust in soybeans. Crop Science 23: 237-239.

19. Hartwig EE (1986) Identification of a fourth major genes conferring to rust in soybeans. Crop Science 26: 1135-1136.

20. Garcia A, Calvo ES, de Souza Kiihl RA, Harada A, Hiromoto DM, et al. (2008) Molecular mapping of soybean rust (Phakopsora pachyrhizi) resistance genes: discovery of a novel locus and alleles. Theor Appl Genet 117: 545-553.

21. Li S, Smith JR, Ray JD, Frederick RD (2012) Identification of a new soybean rust resistance gene in PI 567102B. Theor Appl Genet 125: 133-142.

22. Pham TA, Miles MR, Frederick RD, Hill CB, Hartman GL (2009) Differentia responses of resistant soybean genotypes to ten isolates of Phakopsora pachyrhizi. Plant Disease 93: 224-228.

23. Borém A (1999) Melhoramento de espécies cultivadas. Viçosa, Brasil: Universidade Federal de Viçosa. 
24. Nakamura H (1980) Desirable qualities of soybeans: Japanese view point. In: Frederick TC, eds. World Soybean Research Conference 1980. Granada, Spain: 26-27.

25. Matsuo E (2012) Resistência da soja à ferrugem asiática: hibridação, herança e identificação de marcadores microssatélites. Viçosa, Brasil: Universidade Federal de Viçosa, PhD thesis.

26. CONAB (2015) Acompanhamento da safra brasileira de grãos. Brasilia, Brasil: CONAB publication n. 6 .

27. Hirakuri MH, Lazzarotto JJ (2014) O agronegócio da soja nos contextos mundial e brasileiro. Londrina, Brasil: Embrapa Soja publication n. 349.

28. USDA (2015) World Agricultural Production. Foreign Agricultural Service. United States Department of Agriculture: USDA circular series.

29. Green A (1984) Soybean Rust. Pests Not Known to Occur in the United States or of Limited Distribution. United States Department of Agriculture: USDA publication no. 56 .

30. Sinclair JB, Hartman GL (1996) Soybean rust workshop. Urbana, Illinois, USA College of Agricultural, Consumer, and Environmental Sciences, National Soybean Research Laboratory publication.

31. Yeh CC, Tschanz AT, Sinclair JB (1981) Induced teliospore formation by Phakopsora pachyrhizi on soybeans and other hosts. Phytopathology 71 : 1111-1112.

32. Reis EM, Reis AC, Carmona M, Danelli ALD (2012) Ferrugem asiática. In: Reis EM, Casa RT (2012) Doenças da soja: etiologia, sintomatologia, diagnose e manejo integrado. Berthier, Passo Fundo.

33. Alves SAM, Furtado GQ, Bergamin Filho A (2006) Influência das condições climáticas sobre a ferrugem da soja. In: Zambolin L, ed. Ferrugem Asiática da Soja. Viçosa, Brasil: Universidade Federal de Viçosa, Departamento de Fitopatologia: $37-59$

34. Melching JS, Dowler WM, Koogle DL, Royer MH (1989) Effect of duration, frequency, and temperature of leaf wetness period on soybean rust. Plant Disease 73: 117-122

35. Twizeyimana M, Ojiambo PS, Haudenshield JS (2011) Genetic structure and diversity of Phakopsora pachyrhizi isolates from soybean. Plant Pathology 60 719-729.

36. Jorge VR, Silva MR, Guillin EA, Freire MCM, Schuster I, et al. (2014) The origin and genetic diversity of the causal agent of Asian soybean rust, Phakopsora pachyrhizi, in South America. Plant Pathology 64: 729-737.

37. Freire MCM, Oliveira LO, Almeida AMR (2008) Evolutionary history of Phakopsora pachyrhizi (the Asian soybean rust) in Brazil based on nucleotide sequence of the internal transcribed spacer region of the nuclear ribosomal DNA. Genetics and Molecular Biology 31: 920-931.

38. Freire MCM, Silva MR, Zhang XC, Almeida AMR, Stacey G, et al. (2012) Nucleotide polymorphism in the 5.8S nrDNA gene and internal transcribed spacers in Phakopsora pachyrhizi viewed from structural models. Fungal Genetics and Biology 49: 95-100.

39. Zhang XC, Freire MCM, Le MHG (2012) Genetic diversity and origins of Phakopsora pachyrhizi isolates in the United States. Asian Journal of Plant Pathology 6: 52-65.

40. Vittal R, Yang HC, Hartman GL (2012) Anastomosis of germ tubes and migration of nuclei in germ tube networks of the soybean rust pathogen Phakopsora pachyrhizi. European Journal of Plant Pathology 132: 163-167.

41. Isard SA, Gage SH, Comtjois P, Russo JM (2005) Principles of the atmospheric pathway for invasive species applied to soybean rust. Bio Science 55: 851-861.

42. Buitrago-Posada ML, Boore JL, Frederick RD (2005) Soybean Rust Genome Sequencing Project. In: Proceedings of the National Soybean Rust Symposium, Nashville, USA.

43. Duplessis S, Joly DJ, Dodds PN (2012) Rust Effectors. In: Martin F, Kamoun S eds. Effectors in Plant-Microbe Interaction. Chichester: John Wiley and Sons, Ltd, 155-193.

44. Gill US, Lee S, Mysore KS (2015) Host versus nonhost resistance: distinct wars with similar arsenals. Phytopathology 105: 580-587.

45. Jones JD, Dangl JL (2006) The plant immune system. Nature 444: 323-329.

46. van de Mortel M, Recknor JC, Graham MA, Nettleton D, Dittman JD, et al.
(2007) Distinct biphasic mRNA changes in response to Asian soybean rust infection. Mol Plant Microbe Interact 20: 887-899.

47. Parlevliet JE (1979) Components of resistance that reduce the rate of epidemic development. Annual Review of Phytopathology 17: 203-222.

48. Ribeiro Do Vale FX, Parlevliet JE, Zambolim L (2001) Concepts in plant disease resistance. Brazilian Phytopathology 26: 577-589.

49. Miles MR, Bonde MR, Nester SE, Berner DK, Frederick RD, et al. (2011) Characterizing resistance to Phakopsora pachyrhizi in soybean. Plant Disease 95: $577-581$

50. Flor HH (1955) Host-parasite interaction in flax rust - its genetics and other implications. Phytopathology 45: 680-685.

51. Bonde MR, Nester SE, Austin CN, Stone CL, Frederick RD, et al. (2006) Evaluation of virulence of Phakopsora pachyrhizi and P. meibomiae isolates. Plant Disease 90: 708-716.

52. Marchetti MA, Uecker FA, Bromfield KR (1975) Uredial development of Phakopsora pachyrhizi in soybeans. Phytopathology 65: 822-823.s

53. Walker DR, Harris DK, King ZR, Li Z, Boerma HR, et al. (2014) Evaluation of soybean germplasm accessions for resistance to Phakopsora pachyrhiz populations in the southeastern United States, 2009-2012. Crop Science 54 1673-1689.

54. Yeh CC, Sinclair JB, Tshanz AT (1982) Phakopsora pachyrhizi: uredial development, uredospore production and factors affecting teliospore formation on soybeans. Australian Journal Agriculture Research 33: 25-31.

55. Wang TC, Hartman GL (1992) Epidemiology of soybean rust and breeding for host resistance. Plant Prot Bull 34: 109-124.

56. Miles MR, Frederick RD, Hartman GL (2006) Evaluation of the soybean germplasm for resistance to Phakopsora pachyrhizi. Plant Health Progress Online.

57. AVRDC (1992) Annotated bibliography of soybean rust (Phakopsora pachyrhiz Sydow). Asian Vegetable Research and Development Center (AVRDC). Library Bibliography series 4-1, Tropical Vegetable Information Service. AVRDC. p: 160.

58. Tschanz AT, Tsai MC (1983) Evidence of tolerance to soybean rust in soybeans. Soybean Rust Newsletter 6: 28-31.

59. Kawuki RS, Tukamuhabwa P, Adipala E (2004) Soybean rust severity, rates of rust development and tolerance as influenced by maturity period and seasons. Crop Protection 23: 447-455

60. Yang CY (1977) Soybean rust in the Eastern Hemisphere. In: Ford RE, Sinclair JB, eds. Rust of Soybean: The problem and research needs. Urbana, Illinois, USA: 22-33. 1977

61. McLean RJ (1979) Histological studies of resistance to soybean rust Phakopsora pachyrhizi. Australian Journal Agriculture Research 30: 77-84.

62. Singh BB, Thapliyal PN (1977) Breeding for resistance to soybean rust in India In: Ford RE, Sinclair JB, eds. Rust of soybeans, the problem and research needs. Urbana, Illinois, USA: Int. Agric. Pub., INTSOY publication p: 12.

63. Tschanz AT, Shanmugasundaram S (1985) Soybean Rust. In: Shibles R, ed Proceedings of the 3rd World Soybean Research Conference, Ames, lowa USA: $562-567$

64. Hartman GL, Miles MR, Frederick RD (2005) Breeding for resistance to soybean rust. Plant Disease 89: 664-666.

65. Kendrick MD, Harris DK, Ha BK, Hyten DL, Cregan PB, et al. (2011) Identification of a second Asian soybean rust resistance gene in Hyuuga soybean. Phytopathology 101: 535-543.

66. Chen H, Zhao S, Yang Z, Sha A, Wan Q, et al. (2015) Genetic analysis and molecular mapping of resistance gene to Phakopsora pachyrhizi in soybean germplasm SX6907. Theor Appl Genet 128: 733-743.

67. Hyten DL, Hartman GL, Nelson RL, Frederick RD, Concibido VC, et al. (2007) Map location of the Rpp1 locus that confers resistance to soybean rust in soybean. Crop Science 47: 837-840.

68. Ray JD, Morel W, Smith JR, Frederick RD, Miles MR (2009) Genetics and mapping of adult plant rust resistance in soybean $\mathrm{PI} 587886$ and $\mathrm{PI} 587880 \mathrm{~A}$ Theor Appl Genet 119: 271-280.

69. Kim KS, Unfried JR, Hyten DL, Frederick RD, Hartman GL, et al. (2012) Molecular mapping of soybean rust resistance in soybean accession PI 561356 
Citation: Rosa CRE, Spehar CR, Liu JQ (2015) Asian Soybean Rust Resistance: An Overview. J Plant Pathol Microb 6: 307. doi:10.4172/21577471.1000307

and SNP haplotype analysis of the Rpp1 region in diverse germplasm. Theor Appl Genet 125: 1339-1352.

70. Chakraborty N, Curley J, Frederick RD, Hyten DL, Nelson RL, et al. (2009) Mapping and confirmation of a new allele at Rpp1 from soybean PI594538A conferring RB lesion-type resistance to soybean rust. Crop Science 49: 783-790.

71. Smith JR, Ray JD, Morel W, Frederick RD, Walker DR (2015) Resistance to Phakopsora pachyrhizi in Soybean PI 587905 Maps to the Rpp1 Locus and Exhibits Variable Dominance Associated with Plant Ontogeny. Journal of Crop Improvement 29: 581-601.

72. Yorinori JT (2008) Soybean germplasm with resistance and tolerance to Asian rust and screening methods. In: Kudo H, Suenaga K, Soares RM, Toledo A eds. Facing the challenge of soybean rust in South America. Tsukuba, Japan: JIRCAS Working Report 58: 70-87.

73. Maphosa M, Talwana H, Tukamuhabwa $P$ (2012) Enhancing soybean rust resistance through Rpp2, Rpp3 and Rpp4 pair wise gene pyramiding. African Journal of Agricultural Research 7: 4271-4277.

74. Yamanaka N, Yamaoka Y, Kato M, Lemos NG, Passianotto, ALL, et al (2011) Development of classification criteria for resistance to soybean rust and differences in virulence among Japanese and Brazilian rust population. Tropical Plant Pathology 35: 153-162.

75. Lemos NG, Braccini AL, Abdelnoor RV, Oliveira MCN, Suenaga K, et al. (2011) Characterization of genes Rpp2, Rpp4, and Rpp5 for resistance to soybean rust. Euphytica 182: 53-64.

76. Yamanaka N, Lemos NG, Uno M, Akamatsu H, Yamaoka Y, et al. (2013) Resistance to Asian soybean rust in soybean lines with the pyramided three Rpp genes. Crop Breed Appl Biotech 13: 75-82.

77. Singh RP, Hodson DP, Huerta-Espino J, Jin Y, Bhavani S, et al. (2011) The emergence of Ug99 races of the stem rust fungus is a threat to world wheat production. Annu Rev Phytopathol 49: 465-481.

78. Tschanz AT, Wang TC, Tsai BY (1985) Recent advances in soybean rust research. In: Shanmugasundaram S, Sulzberger EW, McLean BT, eds. Soybean in tropical and subtropical cropping systems. Shanhua, Taiwan: AVRDC, 237-245.

79. Ribeiro AS, Toledo JFF, Ramalho MAP (2009) Interferência da interação genótipos $\mathrm{x}$ ambientes no controle genético da resistência à ferrugem asiática da soja. Pesquisa Agropecuária Brasileira 44: 1160-1167. 